\title{
The Constant Search for New Sustainable Funding Sources for Public Universities
}

\author{
Peter William Mathieson
}

\begin{abstract}
Although publicly-funded universities receive financial support from governments for teaching, research and infrastructure, they require additional sources of income in order to survive and thrive, and particularly to allow innovation and strategic development. It is amongst the responsibilities of the university leadership to ensure financial viability and to seek novel sources of funding, tasks for which they are not always well-trained. In this chapter, the author draws on his experience as a university leader on two continents to illustrate the possibilities as well as some of the hurdles and challenges. The chapter includes sections on philanthropy; alumni relations; industry/business relationships; commercialisation of research; and digital technologies \& future horizons. Universities need to diversify their income streams, invest to succeed and get better at demonstrating their societal worth. Education is one of the most powerful tools of social and economic mobility. The world needs us to succeed!
\end{abstract}

\section{Introduction}

The recent designation of King Abdulaziz University (KAU) as one of three in Saudi Arabia to enjoy autonomy in academic, financial and administrative affairs under the new University By-Law is an exciting moment in the history of the university. It gives the University greater independence in conducting its duties. It also brings a significant challenge: to flourish as an autonomous organisation in a time of great economic, social and political uncertainty. The world is wrestling with the consequences of the SARS-CoV2 pandemic, which is far from over at the time of writing, as well

P. W. Mathieson $(\square)$

University of Edinburgh, Edinburgh, Scotland

e-mail: principal@ed.ac.uk as recent complexities in global geo-politics including deteriorations in the United States-China relationship; Brexit, requiring the United Kingdom to re-define its place in the world; population demographics which combine ageing populations with longer life expectancy plus falling birth rates in many parts of the world including the Middle East. Population growth is most marked in the African continent, with the projection that Nigeria will be the world's second most populous country by 2050 , overtaking China. I will return to the significance of the African continent towards the end of this chapter. Universities seeking to succeed in this complicated and challenging world, with the growing pressures of climate change and seismic shifts in energy consumption, will need to diversify their income sources, develop flexible and adaptable policies on recruitment, alumni relations, philanthropy, engagement with industries and businesses, communications and marketing and be more effective than ever before at explaining their strengths and their contributions to society. I will draw from my experience to address these issues from the viewpoint of the member of a KAU's International Advisory Board. My remarks are intended however not to be for just one university but to be for universities and schools more generally.

\section{The Role of a University Leader}

One of the ironies of academic career progression is that university leaders have typically risen through the ranks based on their achievements in research and/or teaching rather than primarily because of their management expertise. Few university leaders have received formal training in finance or human resources, areas which will take up much of their time when in leadership positions. Some will have received training in communications, marketing and/or media interactions but as with finance and personnel matters, university leaders often have more "on the job" experience than formal pre-emptive training. This was certainly 
true for me: in the early years of my professorial career I steadfastly avoided administrative responsibility, preferring to concentrate on research, teaching and clinical medical practice. It was only when my research group had established its international reputation, and the long-term funding of the group was more secure, that I felt able to take on a broader leadership role. I was therefore experienced at finance and personnel on a relatively small scale, leading a research group, but needed to rapidly acquire knowledge and experience in larger scale leadership and to take responsibility for subject areas very different from my own. Perhaps one of the responsibilities that weighs most heavily on university leaders is the one under discussion in this chapter: securing resources for the continuation, development and (hopefully) expansion of one's university. The careers and livelihoods of so many others depend on the success or failure of university leaders in this domain, so that this can be an onerous responsibility and one of the most troublesome issues which can keep university leaders awake at night. This is true for university leaders all over the world: whether in a public or a private system, whether in a comprehensive or a focused university, whether in a developed country or a developing one. If asked to define the role of a university leader in a single phrase, I say "to protect and enhance the university's reputation". The harsh reality is that now and increasingly into the future, the role is also to ensure the university's future existence. Finding sustainable finance is a key part of this: money isn't everything but it is certainly impossible to run a university without it! Therefore the university leader of today must be a communicator; fund-raiser; capable of interacting successfully with governments, media, alumni, philanthropists, industrialists, business leaders, venture capitalists and the general public as well as with their own students and staff. There isn't a training course: maybe we should start one.

\section{International Variations in the Funding of "Public" Universities}

Universities in the UK are predominantly public organisations, that is they receive some funding directly from government, derived in turn from public taxation. Whilst this has been true throughout my career, in the last 22 years, since university tuition fees were first introduced by the Labour Government in 1998, there has been a progressive shift from public (Government) funding of universities in the UK to a mixed economy where an increasing proportion of income comes from students and their families and other supporters, and a reducing proportion comes directly from Government in the form of block grants. The situation in Scotland has been different from the rest of the UK since 2007 when the Scottish Government, whose devolved powers from the
Westminster (London) Government include responsibility for education, decided that Scottish-domiciled undergraduate students should not pay tuition fees and their tuition costs would be under-written by government funding directly to universities in support of a capped number of undergraduate places. Therefore at Scottish universities there is a complex fee landscape for undergraduate students: "home" students (domiciled in Scotland) pay no tuition fees; students from the rest of the UK pay the same as they would in England; international students pay more. In other parts of the UK there are also some differences: in Northern Ireland, undergraduate fees are capped at less than half the level in England; in Wales there is a modest reduction in fees compared to England.

Research funding in the UK includes substantial levels of Government funding, much of it under the auspices of United Kingdom Research \& Innovation (UKRI) but also some funding schemes from other government departments (Health, Foreign Office, Business etc.). Non-governmental research funding comes from industry and businesses, from charities and from diverse non-governmental organisations. For a large research-intensive university like the University of Edinburgh, a rough estimate is that one third of our funding comes directly from tuition fees, about $20 \%$ from government grants and almost $50 \%$ from other sources including research funding, philanthropy, industry, service provision (accommodation, catering and events) [1]. Similar universities in England would receive a slightly higher proportion from tuition fees and a slightly lower proportion directly from government, because of the difference in government attitudes to "home" tuition fees outlined above.

There is a key point to note here: research funding in the UK does not cover the full costs of the research, and therefore the research requires cross-subsidy from other sources of income. This is mainly from international student tuition fees, which are not capped in the same way that home fees are capped, and from activities such as accommodation, catering and events where universities can generate surplus (not "profit" as such because we are non-profit organisations, but financial surplus which can be re-invested into the activities of the university). It is also a fact that research funding is "money in, money out": it is spent entirely on the costs of research, topped up as necessary by the cross-subsidy described above, and does not contribute to the "bottom line". Therefore in consideration of the funding that is available to the leadership of a university to invest into new buildings, new staff or new activities, research grants are largely irrelevant. Research excellence contributes very substantially to reputation, not least because most of the international league tables are very heavily weighted towards the recognition of research excellence, but it does not help the finances of the university directly. It is my firm opinion that these facts are poorly understood by many 
academic staff as well as by the public and until recently also by governments. One "silver-lining" of the recent SARS-CoV2 pandemic is that the fragility of a research funding system which depends so heavily on cross-subsidy from international student tuition fee income as well as on external events such as conferences has been clearly exposed. The UK Government has now recognised this and is trying to respond, although public finances will clearly be very difficult for the next few years as a result of the economic recession which will follow the pandemic, super-imposed on the uncertainties created by Brexit. University leaders will need to look for new and different sources of funding with even more urgency than before.

The university system in Hong Kong is predominantly also publicly funded, in fact to a greater degree than in the UK because tuition fees charged to home students remain relatively low and almost all research funding comes from governmental sources. There are a few small private universities in Hong Kong but the majority of higher education provision is in eight government-funded universities. Competition for places is intense and many Hong Kong students either have to go abroad to seek university education or attend a community college or similar tertiary organisation in Hong Kong, many of which have articulation pathways into universities. When I was President of the University of Hong Kong (HKU), the oldest and highest-ranked of Hong Kong's universities, about $10 \%$ of our income came from philanthropy, reflecting the extreme generosity of benefactors, both alumni and non-alumni, towards HKU. Other universities in Hong Kong also benefited from philanthropy during that period, although to lesser extents than HKU. By contrast, although at the University of Edinburgh we have just completed our best ever year in terms of philanthropic income, it still "only" represents about 3\% of our total income. The university system in Hong Kong is intermediate in its dependence on philanthropic income between the UK, where philanthropy even in the most successful universities still represents a small proportion of income, and the United States of America (USA) where this type of funding is so crucially important.

I have never worked in the USA system, but I do have some knowledge of it based on my work as a Trustee of CASE, the Council for Advancement and Support of Education, a global organisation based in Washington DC [2] and also from visiting US universities and colleges and talking to university leaders there and at numerous conferences and events over the years. There are over 4300 degree-awarding institutions in the USA, including around 3000 "4 year colleges" which equate to universities elsewhere in the world. $38 \%$ of the institutions are public, $39 \%$ are private not-for-profit, $23 \%$ are private for-profit. Therefore the tertiary education system is much more heterogeneous in the USA than it is in UK or Hong Kong. There is much that universities elsewhere in the world can learn from the USA, both in how to do things and how not to. CASE has changed its remit in recent years from being a predominantly USA-based organisation for the advancement profession to one with a much more global perspective. One of the primary motives for this has been the recognition that educational institutions elsewhere in the world can learn a lot about what works well in the US system and what does not, and can apply this learning into testing new initiatives and ideas in their own settings. Private American universities do receive some government funding, particularly for research, but public universities generally receive a higher proportion of their core funding from state (especially) or federal governments. Tuition fees are higher in private universities, which also tend to have higher endowments, the income from which is critically important to their sustainability. For example Harvard has an endowment of over 40 billion US Dollars which provided $35 \%$ of the university's total revenue in Fiscal Year 2019 [3]. In addition, 9\% of Harvard's revenue came from philanthropic gifts. By contrast, the top ranked public university in the US is Michigan-Ann Arbor at number 21 in the world [4] and it receives an estimated $14.1 \%$ of its funding from the Michigan state government and $73.4 \%$ from tuition fees [5] leaving only $12.5 \%$ for other sources of income including endowment income, philanthropy etc.

\section{Lessons for Universities Elsewhere in the World}

It is a source of regret that universities world-wide are progressively less able to rely upon government funding. As the number of universities has increased, and the proportion of people attending university has risen, it was inevitable that governments would be less able to support universities. This was true even before the deep global recession which is predicted to follow the SARS-CoV2 pandemic, but will be even more the case now. It takes many years to build up endowments, and few universities in the world are as fortunate as the large private American universities like Harvard (funded in 1636 and the oldest institution of higher learning in the United States) to be able to rely on huge income from a massive endowment. Most of the rest of us live in a world where our existence is more fragile. The endowment of the University of Edinburgh is 460 million GBP, equivalent to 601.8 million US Dollars, about $1.5 \%$ of the size of Harvard's endowment, and an amount of money representing less than half of our annual operating costs whereas Harvard has over 7 years' worth of operating costs in its endowment. Edinburgh is one of the most secure of UK universities and yet is financially poor compared to Harvard. How can we ensure the sustainability of our public universities? (Table 1). 
Table 1 Alternative sources of income

Philanthropy

Industry/business

Commercialisation of research

Digital technologies and future horizons

\section{Alternative Sources of Income}

\subsection{Philanthropy}

I have mentioned philanthropic income above. This is a major potential source of additional income, but requires investment in fund-raising infrastructure and expertise and also shows marked international variation. In the UK, where education has traditionally been paid for out of general taxation (albeit no longer substantially the case, as outlined earlier, this is still very much the public perception) and people feel that they have already paid for education, so why should they pay again? Isn't it the government's responsibility to pay? These are comments that I have heard from potential donors in the UK. It is interesting that although the same is true in Hong Kong about public funding of education, wealthy people there seem to need less persuasion that education, especially universities, are worthy of further investment. Some of this might be because of the very powerful intrinsic belief in the importance of education that undoubtedly characterises the Hong Kong population. This is also true in some other East Asian cultures, although the distribution of wealth in some parts of East Asia makes it more difficult for large numbers of people to contribute significant sums. American universities, both public and private, do an excellent job of creating and maintaining a sense of community in their populations; one friend remarked to me that from the first moment that a student speaks on the telephone (or these days online) to an American university, they become a member of the university community that will be nurtured and incubated so that they are motivated to contribute to that community for the rest of their lives. This led me to a concept that I developed during my time at HKU and have continued at Edinburgh: think of students not just as students but as "future alumni". Help them to feel that they are members of a lifelong community. Encourage them to support future generations in benefiting from a university education in the same way that they have benefited. Another very wise remark made to me, by the Provost of a major private American university, was that when speaking to potential donors, he says "someone that you will never know contributed to the costs of your university education. All that I am asking you to do now is to do the same for someone else". This is a very powerful tool: university education transforms lives and the people whose lives have been transformed will often become wealthy and/or influential themselves and can form a pool of willing and able contributors to their university's future. One aspect of the United States system that intrigues me is that the system allows mobility, credit transfer, switching allegiance between one college or university and another, multiple degrees etc. and yet this phenomenon of alumni loyalty remains strong. Wealthy Americans will often donate to more than one alma mater (although it does seem perverse that sometimes the larger donations are to the wealthier or more-established universities rather than to the smaller, younger or less-established institutions that need the support even more). Harvard, the wealthiest of all American universities as well as the oldest, didn't achieve an endowment of 40 billion USD without being able to persuade donors that despite its wealth, it can still benefit from further investment. One mechanism is to ensure that wealth is used to support those that are less wealthy: large private universities in the USA use their endowments to provide a lot of support for applicants from less wealthy origins, in the form of scholarships and bursaries. In my opinion, this is one of the best uses of philanthropic income: levelling the playing field for less advantaged people and at the same time creating opportunity for new successful alumni, who will in turn themselves likely see the transformational power of education and be prepared to invest in it for others.

A striking feature of the philanthropy that I experienced in Hong Kong was that many of HKU's major donors were not alumni. In many cases they were not alumni of any university, not having benefited from tertiary education themselves, or in some cases even from secondary education, but able to appreciate the power of education so that, having become wealthy, they were prepared to invest in universities for the future. My major learning from that period was that donors need to believe in a vision. University leaders must be able to describe a future where universities will contribute to new knowledge and new societal development. For some donors, the subject area will be tightly focused: medicine and healthcare is probably the most frequent example, or within that, cancer or stem cells or cardiovascular disease or suicide prevention. Finding out what the potential donor is most interested in, and aligning that with what your university can contribute, is absolutely at the centre of the advancement professional's job. I have also found that additive or synergistic motivation is also very powerful: with current funding (e.g. from government or tuition fees) we can achieve $\times$ but with additional investment we could achieve $2 \times$ or $3 \times$. Donors generally like to see matched funding or at least a contribution from government and/or from the university itself, so that they feel that their donation gives additional impetus to something that has already inspired confidence from others. 
A particular phenomenon in philanthropic giving to universities, very important in Hong Kong and also often so in the USA, is the power of naming. Assigning one's own name, or the name of a family or Foundation, or (especially in Hong Kong's case) of a revered relative, often a father recently or long-deceased, to a building or lecture theatre or monument, is a powerful desire and wealthy people are prepared to pay for it. In the USA, such naming agreements are often time-limited: say 20 or 25 years, sometimes in the expectation that buildings will only last that long (an interesting concept to the Principal of the University of Edinburgh, where some of our buildings are hundreds of years old!) and this is a good way of managing expectations and also possibly of encouraging a further donation to maintain or renew a naming if the donor or successors so wish.

The complete opposite is the wish of some donors to remain anonymous. There are numerous possible reasons for this: my view is that donors' wishes should be respected but of course anonymity does not mean that the due diligence applied to the propriety of any donor and their motivation should be any less than for a named and publicised donation.

If a university wishes to enhance its philanthropic income, it must be prepared to invest in advancement professionals and expertise, working on alumni relations, on relationships with non-alumni individuals and Foundations, and closely linked with communications, marketing, branding, merchandise etc. There is much to be learned from American universities, although I have frequently encountered strong feelings amongst American alumni that some universities overdo the asking, and there is donor fatigue. Getting the balance right is an art.

\subsection{Industry/Business}

The relationship between universities and industry is a patchwork: in some subject areas, for example engineering, the interaction often seems natural, comfortable and well-established. Staff move between sectors or are sometimes jointly employed between a company and an academic institution. Training programmes are shared, with university students spending time gaining work experience at the industrial "coal-face" and business executives providing teaching in universities and often contributing to research programmes and maybe even studying for further qualifications themselves. In other subject areas, the relationship is not so successful: in my own field, medicine, for example, in the early years of my research career it was not common for researchers in the UK to directly engage with industrial partners and there was a sense that universities saw funding from pharmaceutical companies as somehow tainted or less desirable than funding from government agencies or charities. This has seen a welcome change in recent years: medical researchers and drug or device companies often want the same thing and are more powerful if they collaborate. Some of the sensitivity that I have seen in the relationship has undoubtedly been because of money. Industry was seen as wealthy and powerful but motivated by profit. Universities were seen as aloof and snobbish, only interested in industry as a source of funding. Neither stereotype was probably ever true, but the realisation that universities and industrial partners can have a synergistic collaborative relationship is relatively new in my field, for example in drug design. I mentioned earlier that research in the UK is generally under-funded and requires cross-subsidy; an exception is industry-funded research, where a commercial partner is often better able to understand the full costs of research and to be prepared to pay them. Therefore, while industry-funded research is rarely a source of major surplus, it can at least cover its costs so that enhancement of reputation does not need to be cost-subsidised. Contract research, advisory agreements and consultancies can all form useful sources of income for universities and I see the relationship between the business sector and universities as a potential growth area. This is helped by geographical proximity: for example Siemens AG is the largest industrial manufacturing company in Europe and has co-located major activities with university partners in Darmstadt, Germany and in Lincoln, UK. By contrast, Hong Kong has very little manufacturing industry now, so that universities there need to look further afield for industrial partners, often in Mainland China or other parts of East Asia. Physical distance should not be a barrier to industrial collaboration in these days of excellent digital communications, but distance does make it all the more challenging to build new relationships. Universities again need to invest: they need people that understand business and the commercial sector, who can bring together areas of expertise in universities with routes to application and marketing in industry. As with so many things, communication skills are important. The social sciences and humanities must not be marginalised in this thinking: they play vital parts in the understanding of the world's problems and the development of solutions. The recent pandemic is a striking example: although the immediate impact is one on health, the effects on economies, poverty, inequality and social cohesion seem likely to be even greater, long-lived, deeper and harder to solve. Universities must learn from the subject areas where a relationship with industry and the commercial sector seems more obvious, natural and mutually beneficial, and then extend the thinking to other subjects and areas of expertise. Genuine multi-disciplinarity will be the way of the future and this applies to cross-sectoral links as well as to cross-subject links internally in the university sector. 


\subsection{Commercialisation of Research}

This is an area in which in my opinion universities have not yet generally found the right approach. There is a tendency to wish to ensure that if a university researcher makes a major new discovery or innovation, the university will profit accordingly. This can lead to bureaucratic risk-averse processes which actually serve to stifle creativity rather than encourage it. Universities should recognise, reward and incentivise research commercialisation in their promotion and pay procedures. Keeping a share of intellectual property rights for the individual researcher and for the employer obviously makes sense, based on the small chance that a university is sitting on the next Google or Alibaba, but if the legal, governance and regulatory framework that is put in place to cover that small possibility is too oppressive, both individual researchers and the university itself will lose out.

Cultivating a relationship with venture capitalists, using internal or philanthropic funds to "pump-prime" spin-out companies or start-ups, encouraging the development of entrepreneurial skills amongst students and staff, all play a part. In my experience this is best developed at Stanford University's so-called "d.school", full name the Hasso Plattner Institute of Design, whose website [6] encourages donors to give $\$ 5$ million for a Directorship or $\$ 2$ million for a Fellow. Every student is expected to start at least one company. The "design thinking" is brilliant: students are encouraged to go out into the community and talk to people, find out what problems get in the way of their daily life or cause them insurmountable problems, then come back to the university and work on a solution. This is such a better approach than the traditional "invent a gadget and then think of an application for it".

\subsection{Digital Technologies and Future Horizons}

Universities do not have a monopoly on digital technologies, but we must be major exponents of their application and their improvements, as well as the location of debate on their ethics, regulation and law. I have never believed that the advent of digital education, with Massive Open Online Courses (MOOCs) etc., would spell the end of conventional university education. Universities are also home to research and innovation; to communities of scholars and experts; to experts of the future, learning, growing and developing together. MOOCs provide an alternative form of education for those people, often older, in employment or in parts of the world with less access to conventional university education. Much of their content and delivery will depend on universities themselves. However, the world has changed with the recent SARS-CoV2 pandemic. Universities worldwide have been forced by circumstances beyond their control to rapidly switch to online provision of education and assessment. Researchers have been forced to find new ways of working. Our reliance on digital communication has been greater than ever. What does this tell us about the university of the future and how we should seek to fund it? Will we need fewer office buildings if people (for reasons of health safety, minimisation of travel or personal preference) work from home more extensively in the medium to longer term? Will there be a shift away from research that requires particular facilities or locations, towards research which is more flexible, theoretical or based "in silico" rather than in vitro or in vivo? Will governments wish to see more focus on healthcare, both in terms of research and also in the education and training of healthcare workforces? How will these be conducted in the new digital world? This should be seen as an opportunity not a threat. Parts of the world, including but not limited to the African continent, which have previously had less access to conventional university education can in theory be brought into the fold more easily in this new world. Addressing "digital poverty" will be crucial: access to devices, to broadband or wireless connectivity, and to the time required free of caring responsibilities, working duties or the mere act of survival cannot be taken for granted. These workstreams can form income-generating activities for universities, although sensitivity on pricing to take account of affordability in different regions will need to be carefully developed.

Universities can enhance their relevance, and therefore their sustainability because of demonstrable value to society, by turning this latest threat into an opportunity. My mention of the African continent is deliberate, not least because of the population demographics to which I referred in the Introduction: of the next 3 billion people to be born on our planet, 2 billion of them will be in Africa. Areas including Europe and the Middle East will see increasing migration from Africa whilst their own indigenous populations shrink. The ways in which other regions of the world interact with Africa and its population explosion in the next few decades will have a major impact on the world. Surely we can persuade governments, philanthropists, industries and businesses of the logic of active engagement with those parts of the world where the development will be fastest and most urgent? It could be argued that universities are sometimes too inward-looking, too concerned with their own internal woes. My assertion would be that by raising our gaze and seeing the extent to which we can and must influence the future of our world and its inhabitants, we will directly address our own future sustainability. 


\section{Conclusions}

Universities need to diversify their income streams and they have plenty of material with which to do so. Targeted investment will be required to strengthen capacity in fund-raising, alumni relations, branding, marketing and communications. Building industrial links requires effort, investment and lateral thinking. Universities must harness local strengths but also look further afield for suitable partners. Examination of international best practices, a few examples of which I have cited in this chapter, is worthwhile to highlight possible approaches but obviously each university must set its own priorities according to its own social, political and economic context.

Universities must improve their ability to demonstrate their societal worth: solving problems, creating new knowledge, forming new companies which can create new jobs and contributing to local, regional, national and international prosperity. We must harness the brilliance and conscientiousness of our students and staff. We must be hotbeds of innovation and invention. We must collaborate across disciplines, sectors and national and international boundaries to address the existential challenges facing our world: climate change, pandemics, inequality, food security, water, cyber-security, conflict, renewable energy, access to education and healthcare. These are the ways to ensure our future. Universities are highly resilient organisations; some in Europe are many hundreds of years old and have survived wars, social disturbances, political upheavals, famine and disease. However we cannot be complacent, passively holding out our hand to governments and expecting them to underwrite our future. We need to seek new applications of our excellence. We need to convince the small number of wealthy individuals and Foundations in the world that investment in us will yield benefits for society as well as for them. We need to engage with industry and commerce and see them as allies not as threats or competitors. We need to be flexible and innovative in the face of external challenges. We need to collaborate, to foster inter-disciplinarity. We need to focus on our strengths. The collective societal desire to succeed and to improve is best addressed through education. If we are pro-active, finding ways to ensure our

Open Access This chapter is licensed under the terms of the Creative Commons Attribution 4.0 International License (http:// creativecommons.org/licenses/by/4.0/), which permits use, sharing, adaptation, distribution and reproduction in any medium or format, as long as you give appropriate credit to the original author(s) and the source, provide a link to the Creative Commons license and indicate if changes were made. future should not be insurmountable. The world needs us to succeed!

\section{References}

1. https://www.ed.ac.uk/files/atoms/files/201908_uoe_annual_ accounts_2019_29_online.pdf. Accessed 29 Sept 2020

2. https://www.case.org/. Accessed 29 Sept 2020

3. https://finance.harvard.edu/financial-overview. Accessed 29 Sept 2020

4. https://www.topuniversities.com/university-rankings/worlduniversity-rankings/2020. Accessed 29 Sept 2020

5. https://publicaffairs.vpcomm.umich.edu/key-issues/tuition/generalfund-budget-tutorial/. Accessed 29 Sept 2020

6. https://engineering.stanford.edu/get-involved/give/hasso-plattnerinstitute-design. Accessed 29 Sept 2020

Prof. Peter William Mathieson was born in the United Kingdom and educated in the state school system. He was the first member of his family to go to university. He studied medicine in London followed by a Ph.D. at the University of Cambridge during a fellowship funded by the Medical Research Council, who also funded his post-doctoral fellowship. He was appointed as Professor of Renal Medicine at the University of Bristol in 1995 and led the development of an internationally-recognised research group studying the molecular and cellular basis of proteinuria, a cardinal sign of kidney disease. He secured programme grant funding from the Medical Research Council as well as major support from the Wellcome Trust, Kidney Research UK and other funders. For his last six years at the University of Bristol (2008-2014) he served as Dean of the Faculty of Medicine and Dentistry. It was in this role that he had his first substantive experiences of university fund-raising, including during Bristol's Centenary Campaign. He then served (2014-2018) as the 15th President of the University of Hong Kong, the oldest of Hong Kong's eight public universities and the only English-speaking comprehensive university in Greater China. His responsibilities included delivery of the annual operating budget (turnover 9.2 billion Hong Kong Dollars, equivalent to 1.2 billion US dollars or 800 million GB pounds) and major involvement with philanthropy which contributed about $10 \%$ of that income annually. Since 2018 he has been Principal of the University of Edinburgh, one of Scotland's "ancient" universities and ranked in the world's top 20, see: https://www. topuniversities.com/university-rankings/world-university-rankings/2022. The University of Edinburgh has an annual turnover of $£ 1$.1billion, equivalent to 1.4 billion US dollars. In his second year in office he led the University to its highest annual income from philanthropy in its 438 year history. Of the awards he has won in his professional career, he is most proud of the teaching prizes he won in Cambridge and Bristol, and he has continued to contribute to teaching whilst undertaking all of his senior leadership roles. Professor Mathieson is a member of the KAU IAB

The images or other third party material in this chapter are included in the chapter's Creative Commons license, unless indicated otherwise in a credit line to the material. If material is not included in the chapter's Creative Commons license and your intended use is not permitted by statutory regulation or exceeds the permitted use, you will need to obtain permission directly from the copyright holder.

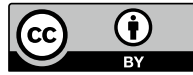

